\title{
Postoperative Shock
}

National Cancer Institute

\section{Source}

National Cancer Institute. Postoperative Shock. NCI Thesaurus. Code C50703.

A state of shock following a surgical operation. 